\title{
PENYELESAIAN SENGKETA PENGgELAPAN HASIL KEBUN DI ATAS TANAH LANDERFORM
}

\author{
Ida Bagus Made Murda Soma Widya, I Made Sepud, I Ketut Sukadana \\ Fakultas Hukum Universitas Warmadewa, Denpasar-Bali, Indonesia
}

\begin{abstract}
Abstrak
Penggelapan merupakan perbuatan yang merugikan perekonomian Negara. Kegiatan penggelapan dilakukan dengan asumsi lebih cepat menghasilkan uang daripada harus bekerja dengan mengikuti peraturan pada perusahaan. Perilaku masyarakat tersebut mencerminkan rendahnya nilai moral. Penelitian ini bertujuan untuk menganalisis pengaturan tentang tanah Landreform dan mendeskripsikan tata cara penyelesaian sengketa penggelapan hasil kebun tanah Landreform. Penelitian ini menggunakan peneilitian hukum normatif dengan pendekatan perundangan-undangan yang berpatokan pada undang-undang sebagai dasar penelitia. Adapun data yang digunakan adalah bersumber dari bahan hukum primer dan sekunder. Hasil penelitian menunjukkan bahwa hukum yang berlaku tidak begitu penting bagi sebagian orang yang memiliki kuasa atas suatu bangunan atau kepemilikan tanah dan lebih memilih kekuasaan dari tanah yang seharusnya bukan menjadi milik pribadi. Adapun pengaturan tentang tanah Land reform adalah sebuah larangan yang ditujukan kepada semua orang yang ingin menguasai lahan tanah diluar kemampuan atau bagiannya tanpa izin dan memberitahukan niatnya terlebih dahulu kepada orang lain. Penyelesaian sengketa penggelapan hasil kebun tanah landreform dapat diselesaikan dengan cara non litigasi (diluar pengadilan) dan litigasi (dipengadilan).
\end{abstract}

Kata kunci: Penyelesaian Sengketa; Penggelapan Hasil Kebun; Lander Form

\begin{abstract}
Embezzlement is an act that is detrimental to the country's economy. Embezzlement activities are carried out on the assumption that making money is faster than having to work by following the rules of the company. Community behavior reflects low moral values. This study aims to analyze the arrangement of and describe the procedures for settling disputes over embezzlement of Landreform land crops. This research uses normative legal research with a statutory approach that is based on law as the basis for research. The data used are sourced from primary and secondary legal materials. The research results show that the applicable law is not so important for some people who have power over a building or land ownership and prefer power over land that should not be private property. As for the regulation of Landreform is a prohibition aimed at all people who want to control land beyond their ability or part of it without permission and notify their intentions in advance to others. Settlement of disputes over embezzlement of land reform land products can be resolved by non-litigation (outside the court) and litigation (in court).
\end{abstract}

Keywords: Dispute Resolution; Embezzlement of Garden Products; Lander Form

\section{PENDAHULUAN}

Hukum yang berlaku di Indonesia saat ini bukan menjadi suatu yang harus diikuti dan dilaksanakan oleh masyarakat banyak diantaranya yang tindak melanggaar aturan hukum dikarenakan belum terkenanya sanksi karena selama ini selalu bisa menyembunyikan perbuatannya. Sosialisasi mengenai pentingnya hukum di Negara ini sudah sering dilakukan namun belum semua warga mau mengikuti aturan yang berlaku (Sagama, 2016). Bahkan ketika seseorang sudah pernah mendapat hukuman dari apa yang diperbuatnya orang itu juga tetap melanggar aturan baik itu perbuatan yang disengaja ataupun tidak seolah hukum menjadi hal yang biasa saja tanpa memikirkan akan merugikan orang lain. Perlunya sikap saling sadar diri dalam menjalani kehidupan dengan mematuhi setiapp peraturan yang telah diberlakukan (Andrian, 2017). Hak asasi manusia harus dilindungi dalam kondisi apapun tidak jika perbuatan seseorang melanggar peraturan. Pihak-pihak terkait tentang keamanan dan ketertiban negara berperan penting dalam memberi contoh bagaimana seharusnya seseorang bertindak dan mematuhi peraturan. Mesekipun berbeda divisi mulai dari kepolisian, kejaksaan, TNI semua memiliki tugas yang sama dalam membuat Indonesia menjadi negara yang taat hukum dan memiliki sanksi bagi seseorang yang dengan sengaja atau tidak melalukan perbuatan yang bertentangan dengan hukum positif. 
Kejahatan dapat dilakukan dimana saja dan kapan saja segala perbuatan dapat dianggap melanggar aturan jika tujuan dari perbuatan tersebut mencederai, melukai dan menghilangkan nyawa terlebih jika perbuatan tersebut telah direncanakan sedemikian rupa maka dapat dikatakan perbuatan itu adalah kejahatan berencana dengan hukuman yang lebih berat dari kejahatan biasa (Samosir, 2012). Indonesia banyaknya kejadian yang beraneka ragam motif dan caranya melakukan suatu kejahatan ada yang dengan sengaja melakukan kejahatan didasari rasa iri dan ada berdasarkan ingin menguasai kekayaan seseorang. Pemerintah melarang keras perbuatan yang dapat merugikan seseorang maka pemerintah membuat aturan-aturan yang dapat membatasi tingkah laku seseorang namun aturan tersebut tidak digubris oleh masyarakat yang beranggapan bahwa orang yang mengikuti aturan hukum adalah orang lemah yang terlalu takut akan perbuatannya. Pola pikir yang sampai saat ini tidak bisa dihilangkan oleh pihak pemerintah karena banyaknya orang-orang yang dengan mudah dipengaruhi pikirannya untuk melakukan sesuatu tanpa tahu efek daripada perbuatan yang dilakukannya.

Penelitian terdahulu mengungkapkan bahwa Secara teoritis, ada empat faktor penting sebagai prasyarat pelaksanaan landreform, yaitu kesadaran dan kemauan dari elit politik, organisasi petani yang kuat, ketersediaan data yang lengkap, serta dukungan anggaran yang memadai. Saat ini, kondisi keempat faktor tersebut masih dalam kondisi lemah, sehingga dapat dikatakan implementasi landreform secara serentak dan menyeluruh di Indonesia masih sulit diwujudkan (Syahyuti, 2016). Menurut Isnaeni, (2017) Politik pembaharuan hukum agraria berparadigma Pancasila belum mampu diwujudkan dalam politik hukum agraria nasional skarena dua alasan yaitu banyak penyimpangan di lapangan dalam pelaksanaan UUPA, kedua aturan pelaksanaan yang dimanatkan UUPA banyak yang belum terealisir hingga saat ini. Untuk itu perlu adanya penegasan dan revitalisasai nilai Pancasila dalam politik hukum agraria nasional, Terutama dalam hal penghormatan hak rakyat terhadap penguasaan dan pemilikan tanah. Timbulnya sertifikat ganda juga disebabkan oleh kurangnya kedisiplinan dan ketertiban aparat pemerintah yang terkait dengan bidang pertanahan dalam pelaksanaan tugasnya (Mulyadi, 2019).

Berbagai macam aturan yang mengikat tingkah laku seseorang dan banyak juga pelanggaran yang dilakukan orang-orang salah satunya penggelapan, kasus yang tiap hari ada saja laporan masuk kepada pihak kepolisian. Di Indonesia seseorang dengan mudah dapat melakukan perbuatan yang bertentangan dengan nilai-nilai pancasila mulai dari pencurian, pemerkosaan, korupsi dan penggelapan. Ekonomi seseorang yang menyebabkan maraknya tindak pidana penggelapan demi mendapatkan uang untuk dirinya sendiri seseorang rela melakukan sesuatu yang merugikan banyak orang, perbuatan ini membuat pecah belah persatuan masyarakat karena banyaknya kasus penggelapan maka semakin banyak masyarakat yang menaruh rasa curiga kepad setiap orang. Bila keadaan ini terus menerus maka negara tidak akan menjadi negara maju maka akan menjadi negara mundur karena pudarnya nilai-nilai kemanusiaan dalam diri rakyat Indonesia sampai saat ini. Bertolak dari dari kejadian ini maka peneliti ini dilakukan dengan tujuan untuk menganalisis pengaturan tentang tanah Landreform dan mendeskripsikan tata cara penyelesaian sengketa penggelapan hasil kebun tanah Landreform.

\section{METODE PENELITIAN}

Penelitian ini didesain dengan Penelitian hukum normatif adalah hukum kepustakaan yang mengacu pada norma hukum yang terdapat dalam peraturan Perundang-undangan (Waluyo, 2002). Pendekatan yang digunakan adalah Pendekatan perundangan-undangan yaitu melakukan suatu penelitian dengan berpatokan pada undang-undang. Pendekatan kasus dilakukan guna melihat, mencatat dan memahami permasalahan yang diteliti dengan tidak keluar dari zona hukum positif. Adapun sumber data yang digunakan adalah data primer dan sekunder, penerapan metode normatif dan kualitatis menelaah lebih mendalam dan spesifik isu hukum yang didasari peraturan-peraturan hukum Perbankan di Indonesia (Ahmad, 2008).

\section{HASIL DAN PEMBAHASAN}

\section{Pengaturan Tentang Tanah Landreform}

Reformasi tanah yang dalam hal ini sering disebut reformasi agraria dalam arti luas dapat meliputi pelaksanaan pembaharuan hukum pertanahan atau agraria dengan tujuan penghapusan hak-hak asing dan konsesi-konsesi colonial hak atas tanah. Untuk mengakhiri rongrongan dan 
penghisapan atas iklim feodal yang ada, secara berangsur-angsur perombakan mengenai kepemilikan dan kepenguasaan tanah serta hubungan hukum terhadap orang yang bersangkutan dengan penguasaan tanah, dan peruntukan bumi, perencanaan persediaan air dan kekayaan alam yang terkandung di dalamnya secara berencana yang sesuai dengan daya kesanggupan dan kemampuan masyarakat, maka pelaksanaan reformasi agraria merupakan kebijakan yang berpihak pada keadilan masyarakat dan dikenal sebagai kebijakan Land Reform. Reforma agraria atau reformasi kebijakan mengenai tanah dalam arti sempit dapat diartikan perombakan mengenai kepemilikan dan kepenguasaan tanah serta hubungan hukum atau aturan yang bersangkutan dengan penguasaan tanah. Pada tataran implementasinya, istilah Landreform sering diidentikkan atau dipadankan dengan istilah agrarian reform atau disebut reforma agraria, karena kebijakan aturan landreform secara langsung dapat menunjukkan hasil yang lebih nyata melalui perombakan penguasaan dan pemilikan tanah yang lebih berkeadilan bagi masyarakat dan dapat secara langsung dapat dirasakan oleh seluruh lapisan masyarakat.

Menurut Wiradi, (2008) kebijakan sistem penguasaan tanah meliputi pengaturan-pengaturan yang dilakukan secara legal maupun adat dimana dengan hal tersebut petani dapat memperoleh akses terhadap kesempatan-kesempatan produktif atas tanah serta mendapatkan hak atas tanah tersebut. Sistem ini merupakan sistem yang mengatur tatanan dan prosedur tentang hak, kebebasan dalam penggunaan, kewajiban, dan pengawasan sumber daya agraria khususnya tanah dan air. Dengan kata lain dapat dikatakan bahwa sistem penguasaan tanah turut membentuk keadilan dimana pola penyebaran pendapatan dalam sektor pertanian, oleh karenanya reformasi agraria atau landreform berarti mengubah dan menyusun kembali tatanan dan prosedur didalam usaha membuat sistem penguasaan tanah itu dan konsisten dengan persyaratan secara keseluruhan dari pembangunan ekonomi (Wiradi, 2008)

\section{Tata Cara Penyelesaian Sengketa Penggelapan Hasil Kebun Tanah Landreform}

Tujuan dari sebuah reformasi tentang agraria atau landreform pada dasarnya adalah untuk menyempurnakan pemerataan kepemilikan tanah. Dalam tujuan ini terdapat 2 (dua) dimensi dasar yaitu :

1. Untuk menciptakan kesetaraan hidup masyarakat semua hak dan kewajiban para pemilik tanah di bagi rata sesuai dengan bagian masing-masing agar kedepan tidak terjadi keributan yang berujung terjadinya suatu kejahatan

2. Agar daya guna sebuah tanah sesuai dengan fungsinya dan menjadikan keadaan yang sejuk dan tenang.

Sebidang tanah di Indonesia sangat berarti bagi seseorang maka pemerintah menetapkan landreform untuk memfungsikan tanah sesuai dengan seharusnya dan perbuatan pemerintah tidak melenceng dari pancasila dan undang-undang dasar. Fungsi dari landreform ini adalah sebagai sarana bagi para petani atau pemilik tanah dalam usahanya memperkuat kepemilikan hakatas tanah yang dimilikinya sesuai dengan bagiannya masing - masing, kebijakan tersebut juga bertujuan sebagai pemerataan bagi setiap hak dan kewajiban yang didapat oleh seseorang yang memiliki tanah tersebut demi terciptanya suatu keharmonisan di dalam masyarakat. Menurut Hutagalung, (2010)Tujuan tujuan Landreform sebagai berikut :

1. Membuat setiap masyarakat yang memiliki hak atas sama dengan yang lainnya tanpa adannya pengakuan sepihak atas tanah yang dimiliki dan kedepan diharapkan semua pemilik tanah agar sadar diri dengan kepunyaannya sendiri tanpa mengambil alih hak milik orang lain demi keuntugan pribadi.

2. Membuat fungsi tanah sesuai dengan porsinya masing-masing. Sebagai seorang petani atau pemilik atas tanah diharapkan menggunakan secara bijak tanah tersebut seperti dipergunakan untuk menambah penghasilan, membuat indah keadaan sekitar apapun itu dengan tujuan yang benar tanpa ada rasa ingin memiliki hak milik orang lain (Arie, 2010) Pemerintah menerapkan landreform sebagai upanya untuk mengembalikan

fungsi tanah dan pemerataan bagi pemilik tanah dengan memikirkan beberapa aspek diantaranya

1. Aspek tujuan sosial ekonomi 
Menggunakan secara bijak lahan tanah yang dimiliki untuk keperluan positif dan bisa digunakan untuk meningkatkan perekonomian seperti menyewakan tanah dalam jangka waktu lama, dipergunakan untuk bercocok tanam dan kegiatan menghasilkan lainnya

2. Asperk tujuan sosial politik

Menghilangkan pembengkakan lahan tanah yang dimiliki oleh orang-orang yang memiliki kekuasaan demi tercipatanya pemerataan hak masyarakat terhadap tanah.

3. Aspek tujuan mental psikologi

Dengan diberikan hak yang sama bagi setiap orang oleh pemerintah diharapkan memotivasi niat kerja seseorang untuk menghidupi dirinya dan keluarga serta membuat banyak orang percaya kepada masyarakat selalu mengutamakan kepentingan masyarakat.

Namun kebijakan pemerintah dalam pemerataan hak tanah dirasa sejauh ini masih belum tepat karena masih banyaknya masyarakat khususnya petani yang tidak mendapat imbas dari kebijakan masyarakat ini mereka menilai kebijakan ini diberlakukan kepada beberapa orang saja dengan tujuan menarik simpati masyarakat serta nama baik pemerintah. Pembangunan terus dilakukan orang-orang tertentu demi meraih keuntungan dengan menggunakan tanah dengan jumlah yang tidak sedikit. Dengan demikian para petani tidak bisa mencari nafkah demi keluarganya dan tidak adanya keseimbangan seperti yang teriakan pemerintah kepada masyarakat bahwa kebijakan tersebut dapat merubah perekonomian masyarakat.

Menanggapi hal tersebut membuat pemerintah membuat peraturan pemerintah dengan tujuan membuat masyarakat percaya tujuan pemerintah untuk mensejahterakan masyarakat dengan aturan pelaksanaan penggantian tanah dan pemberian ganti rugi atas tanah. Sistem peraturan pemerintah ini yaitu para petani dipersilahkan memiliki tanah tersebut tetapi harus melakukan pendaftaran terebih dahulu, teruntuk masyarakat yang tanahnya dibeli oleh pemerintah akan diberikan uang ganti rugi sebagai ucapan terima kasih.

Penertian hak gadai atas tanah merupakan perjanjian antara kedua belah pihak dimana pihak pertama membayar kepada pihak kedua atas tanah dan pihak satunya lagi menerima hasil gadai tersebut. Apabila terjadi wan prestasi maka para pihak mencari jalan tengah namun pihak yang dirugikan adalah pihak yang telah dibohongi atau dirugikan. Selama uang sewa atas tanah tidak dikembalikan maka selama waktu itu juga tanah tersebut menjadi pihak yang menyewa. Maka dari itu sebelum dibuatnya perjanjian antara para pihak sebaiknya dibicarakan mengenai kemungkinan bila terjadi wanprestasi agar saat

perjanjian telah ditandatangani oleh kedua belah pihak akan sesuai keinginan masing-masing tanpa memikirkan akan terjadi ingkar janji.

Sistem atau hak gadai tanah adalah hubungan hukum antara seseorang dengan tanah kepunyaan orang lain, dimana orang tersebut telah menerima uang gadai daripadanya. Untuk itu selama uang gadai belum dikembalikan maka tanah tersebut tetap dikuasai oleh pemegang gadai. Dan selama itu hasil dari tanah seluruhnya menjadi hak seorang pemegang gadai. Praktek dilapangan mengenai pengembalian uang gadai yang lazimnya disebut penebusan, sangat tergantung pada kemampuan dan kemauan pemilik tanah yang menggadaikan (Harsono, 2007).

Setiap perjanjian yang dilakukan kemungkinan terburuknya adalah ingkar janji dari salah satu pihak karena berbagai macam alasan antara salah satu pihak merasa tidak setuju atas perjanjian yang mengikat namun harus menandatangani ada juga yang ingkar janji karena ingin menguasai hak dari salah satu pihak (Amriani, 2012). Apabila terjadi sengketa maka salah satu pihak ada yang merasa dirugikan dan merasa tidak terima dari perbuatan yang merugikan dirinya, cara menyelesaikannya dapat diselesaikan secara kekeluargaan dan bisa dilakukan dipengadilan. Perjanjian yang telah disepakati bersama tentu harus diikuti bersama jangan ada niat tersembunyi setelah ditandatangani sebuah kontrak, banyak diantara para pelaku usaha melakukan perjanjian tetapi berjalan sesuai dengan kehendak para pihak dan ada juga yang dengan sengaja ingin memiliki hak dari rekan bisnisnya. Perbuatan tersebut tidak bisa dibenarkan karena merugikan atau kelompok lain, Pemerintah mendukung adanya perjanjian diantara kedua belah pihak namun telah membuat peraturan - peraturan yang mengikat orang yang melakukan perjanjian apabila dikemudian hari teradi pelanggaran demi keuntungan sendiri (Rahmadi, 2017). Maka dari itu dibuatlah sanksi bagi seseorang yang dilaporkan melakukan perbuatan ingkar janji disertai ganti rugi atas perbuatannya. Alternatif yang sudah disediakan pemerintah di pengadilan menjadi solusi dari kedua belah pihak yang bersengketa namun jarang digunakan karena banyak memikirkan besar biaya yang akan dikeluarkan 
ditambah lagi prosesnya yang banyak menyita waktu membuat banyak yang beralih menggunakan kepala dingin dalam menemukan jalan tengah atas wanprestasi yang terjadi.

Pada dasarnya penyelesaian sengketa yang baik dilakukan dengan kepala dingin dan tidak perlu mengadu kepada pihak yang berwanang dibidangnya dengan banyak proses dan biaya yang dikeluarkan, kalau bisa cepat dan murah kenapa menggunakan cara lama dan bertele-tele. Untuk menyelesaikan suatu perkara tidak semudah seperti apa yang difikirkan banyak data- data yang harus diisi lalu sebelum mengajukan pengaduan ke pengadilan setelah diproses waktu yang diperlukan untuk maju ke tahap berikutnya juga lumayan lama dan begitu seterusnya sampai akhirnya hakim memutuskan siapa yang benar atau bersalah.

\section{SIMPULAN DAN SARAN}

\section{Simpulan}

Berdasarkan hasil analisis data dapat disimpulkan bahwa Setiap orang yang memiliki tanah berhak mendapatkan haknya untuk mengelola dan menjual agar terciptanya keharmonisan dalam bermasyarakat jangan sampai terjadi rasa iri hati dan secara pihak memutuskan seseuatu wanprestasi. Penyelesaian sengketa penggelapan hasil kebun tanah land reform dapat diselesaikan dengan cara non litigasi (diluar pengadilan) dan litigasi (dipengadilan), dimana dalam kasus yang penulis teliti seharusnya penyelesaian permasalahan didahui dengan cara non litigasi atau diluar pengadilan, akan tetapi korban memilih jalur litigasi untuk dapat membuktikan secara pasti hak atas tanah serta kerugian yang ditimbulkan dari penggelapan yang dilakukan tersangka, yang kedua reformasi tanah yang dalam hal ini sering disebut reformasi agraria dalam arti luas dapat meliputi pelaksanaan pembaharuan hukum pertanahan atau agraria dengan tujuan penghapusan hak-hak asing dan konsesi-konsesi colonial hak atas tanah. Reformasi agraria merupakan kebijakan yang berpihak pada keadilan masyarakat dan dikenal sebagai kebijakan Landreform. Landreform merupakan perubahan kebijakan secara mendasar khususnya mengenai kepemilikan dan penguasaan hak atas tanah serta hubungan-hubungan hukum yang menyangkut dan bersangkutan dengan pengusahaan tanah

\section{Saran}

Adapun yang disarankan oleh peneliti adalah diharapkan Kepada pemerintah agar tetap konsisten melakukan kewajibannya sesuai dengan tugas konstitusi yaitu memberikan keadilan demi kesejahteraan masyarakat khususnya petani dengan cara menegakkan aturan landreform secara tegas, yang kedua Untuk penyelesaian segala bentuk sengketa kepada setiap pihak agar melakukan penyelesaian sengketa dengan non litigasi terlebih dahulu. Hal ini dikarenakan penyelesaian masalah dengan non litigasi akan memberikan rasa keadilan dan kemenangan bagi semua pihak. Dibandingkan dengan penyelesaian masalah dengan pola litigasi pada akhirnya ada pihak yang merasa menang dan juga ada yang merasa kalah, shingga rentan menimbulkan kebencian dan dendam.

\section{DAFTAR PUSTAKA}

Ahmad, B. (2008). Metode Penelitian Hukum. Pustakasetia.

Andrian, A. (2017). Upaya Pembinaan Fisik dan Mental (PFM) dalam Membangun Kedisiplinan Siswa di Smk PGRIi 3 Cimahi. Journal Untirta Civic Education, 2(1), 132-155.

Harsono, B. (2007). Hukum Agraria Indonesia. Djmbatan.

Hutagalung, A. (2010). Hak Penguasaan Tanah Land Reform. Wacana Pustaka.

Isnaeni, D. (2017). Kebijakan Landreform Sebagai Penerapan Politik Pembaharuan Hukum Agraria yang Berparadigma Pancasila. $J u, 1(2), 83-97$.

Mulyadi, S. (2019). Penyelesaian Sengketa Kepemilikan Tanah Bersertifikat Ganda. Jurnal Yuridis, 6(1), 147173.

Sagama, S. (2016). Analisis Konsep Keadilan, Kepastian Hukum dan Kemanfaatan dalam Pengelolaan Lingkungan. Mazahib, 15(1), 20-41.

Samosir. (2012). Hukum Pidana Indonesia. Media Pustaka.

Syahyuti. (2016). Kendala Pelaksanaan Landreform di Indonesia: Analisa terhadap Kondisi dan Perkembangan Berbagai Faktor Prasyarat Pelaksanaan Reforma Agraria. Forum Penelitian Agro Ekonomi, 22(2), 89101.

Waluyo, B. (2002). Penelitian Hukum Praktek. Sinar Grafika.

Wiradi, G. (2008). Pola Penguasaan Tanah Pertanian di Jawa dari Masa ke Masa. Yayasan Obor. 